\title{
IGBO AND CHINESE TONAL SYSTEMS: A COMPARATIVE ANALYSIS
}

\author{
Sunny Odinye* \\ \& \\ Gladys Udechukwu* \\ http://dx.doi.org/10.4314/og.v12i 1.14
}

\begin{abstract}
Chinese language was recently introduced in the department of Igbo, African and Asian Studies of the Nnamdi Azikiwe University, Awka during the 2006/2007 academic session. Although Igbo and Chinese are both tone languages, their tonal systems differ. For this reason, Igbo speaking students find it difficult to study Chinese language. To alleviate the difficulty, this paper attempts to look vividly into comparative analysis of Igbo and Chinese tonal systems. In analyzing this, words from Igbo and Chinese language are selected for an effective comparison.
\end{abstract}

Keywords: Tone, phonology, Chinese, Igbo

\section{Introduction}

There are many languages of the world. Some are intonation languages while some are tone language. Igbo and Chinese languages are grouped under the tone languages of the world. Igbo is a register tonal language while Chinese is a contour tonal language. They are languages in which the tones convey difference in meaning. Tone is a very important aspect of language especially tonal language like Igbo and Chinese.

Phonology cannot be isolated from tone, as it has to do with speech sounds. Since tones are placed on syllables of words and syllables are being created out from tones of a particular word, they are bound together. Anagbogu, Mbah and Eme (2001:30) say that phonology concerns with the exploitation of speech sounds to make meaningful construct. They further expressed that one of the things done in phonology is to be able to identify those meaningful sounds used to convey semantic import. Consider the following Igbo data:

lákál

látá/

lákú/ 'hand'

'weed'

'kernel' 
Phonetics according to Anagbogu, Mbah and Eme (2001:37) "Is that branch of language studies interested in studying the sounds used in language: how the speaker produces these sounds, how these sounds travel to the listener and how the listener eventually hears and understands the speaker". As already mentioned, phonetics studies the mechanism for speech sound production; the characteristics; classification and accurate transcription of speech sounds through the air to the listeners; and the physiology of hearing.

Roach (2003:154) says:

...there is no difference in meaning in such a clear cut way as in Mandarin Chinese, where, for example, mā means 'mother', má means 'hemp' and mă means 'scold', languages such as the above are called tone languages; although to most speakers of European languages they may seem strange and exotic, such languages are in fact spoken by a very large proportion of the world's population. In addition to the many dialects of Chinese, many other languages of Southeast Asia (eg. Thai, Vietnemese) are tone languages; so are very many African languages; particularly those of the South and West, and a considerable number of Native American languages...

\section{Concepts of Igbo Tonal System}

In slow pronunciation of any Igbo word, one could find out that the word falls out in breath by breath. One breath is called syllable. Conversely, any Igbo word is being pronounced syllable by syllable. A syllable is usually made up of a consonant and vowel (cv), thus Yule (1996:57) says "A syllable must contain a vowel (or, vowel like) sound. The most common type of syllable in language also has a consonant before the vowel, often represented as CV'. Example: 
Odinye \& Udechukwu: Igbo and Chinese Tonal Systems...

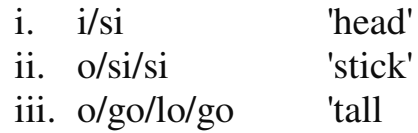

isi in the above examples has two syllables, ' $i$ ' and 'si', osisi has three syllables, 'o', 'si', and 'si' while ogologo has four syllables, 'o', 'go', 'lo' and 'go'. Every syllable has sound; this is because the voice of the person pronouncing these syllables will have series of tones. For examples: isi - two syllables, osisi - three syllables, ogologo - four syllables. All these tones fall in the proper way in order to give meaning to any word that is needed. The sound of these syllables in every word which is produced by the person pronouncing them is what is called "tone".

According to Anagbogu, Mbah and Eme (2001):

A tone language is one which uses tone first to give meaning to a lexical item, which may otherwise appear similar in forms. Tone is seen as a feature realized on the syllables in tone languages. In languages such as the Igbo language in which tone operates, tone is usually realized on the vowel of the syllables or on any other element.

For example in Okuko 'fowl'-tone is realized only on vowels. In mmírí 'water' tone is also realized on the syllabic nasal in the initial position. We can say categorically therefore, that all the tones are realized on the vowels and on the syllabic consonants but never on the consonants in tone languages such as Igbo. When we say that tones differentiate two otherwise identical lexical items, we mean that although two words may be morphologically identical, the tonal element can completely charge the meanings of these otherwise identical words.

Anagbogu, Mbah and Eme (2001) classified system into two. They include: Register tonal system and contour tonal system. 
In a register tone language, tones are essentially level. By this we mean that the pitch of a syllable does not glide from one level to the other during production. An example of a register tone language is Igbo. It has high tone, low tone, down step tone and down drift tone. Contour tone: In this type of tonal system, the syllable undergoes a glide in pitch during production. An example of this is the Chinese language. In fact, most of the tone languages of Asia are contour tone languages, example, Cantonese, Burmese, Mandarin, Thai. Contour tone languages have such gliding tonemes as rising, falling, falling - rising, rising - falling, falling - rising - falling etc.

\section{Importance of Igbo tone}

It is only one prominent role that tone plays in Igbo language. The role it plays is that it gives meaning to morphemes, words, phrases and sentences. Most times, one word, morpheme, phrase and sentence do have varieties of meaning. It is tone that will be used to indicate those varieties of meaning they have. For example, at times one morpheme might have more than one meaning or interpretation. Tone will always assist in bringing out their various meaning. Examples:

1. dí (husband)

dì (endure)

jí (yam)

jì (hold)

2. Word: Most times, one word might have series of meaning, tone is used to differentiate those meaning. Example:

Òbí (name)

Óbì (heart)

$$
\begin{array}{ll}
\text { ọzọ (again) } & \text { áfọ (stomach) } \\
\text { ózọ (animal) } & \text { áfọ (year) } \\
\text { ọzọ (title) } & \text { àfọ (market day) }
\end{array}
$$

3. Phrase: A phrase might have more than one meaning; tone helps in differentiating their meanings. Examples:

Égbè ígwē

Égbē ìgwē

Ísí mbè

Ísí mbè (thunder)

(Igwe's gun)

(Tortise's head)

(somebody's head) 
Odinye \& Udechukwu: Igbo and Chinese Tonal Systems...
Ézé ágụ
(Lion's teeth)
Ézé āgu
(somebody's teeth)

4. Sentence: Tone helps in differentiating one sentence that has series of meaning. Example,
Ó jèrè áhịá
(Declarative sentence)
Ò jèrè áhịá
(Interogative sentence)
Ọ hựu nné yā
(Declarative sentence)
Ọ hưrụ nné yā
(Interrogative sentence)

\section{Types of Igbo tone}

There are four different types of tones in Igbo language. They include: High tone, Low tone, Down step, Down drift. But those that are mostly seen in Igbo words include: high tone, low tone, down step. Down drift is not observed in words but in sentences because one can raise or lowers his pitch before a sentence is completed. These four tones have symbol that they are known for. They include:

High tone (/)

Low tone ( ()

Down step (-)

Down drift (-)

(a) High tone - Just like the name suggests, it rises higher than other tones.

(i) It can follow each other in a particular Igbo word. Example: Óké (male), Ísí (head), Ósísí (tree), Ógólógó (tallness)

(ii) It can follow low tone in a word. Example: Òbí (male, name), Òké (rat), Àdá (female name), Ọsá (squirrel). 
(iii) Low tone can as well follow high tone in an Igbo word. Example: óbì (heart), écè (king), ósè (pepper), úbè (spear), ékè (Gizzard).

(iv) Down step can equally follow high tone in an Igbo word. Example: égō (money), érō (mushroom), ézē (tooth), ózō (chieftaincy title).

Again, if high tone changes in grammatical construction, it becomes down step tone. Example:

ísí + éwú

ísí éwú (goat's head)

ányá + ésú

ányá ésú (millipede’s eye)

In conclusion, it was found that in a word that has two syllables, high tone homogeneity is high high, low high, high low, high down step.

(b) Low Tone: Low tone descends. It can follow each other in an Igbo word. Example: àlà (earth), ùdù (clay pot), ìtè (pot), àkwà (bed). It can follow high tone in a particular Igbo word. Example: Óbì (heart), ósè (pepper), úkwù (waist), ákwà (cloth), úbè (spear). High tone can as well follow low tone in a word. Example: òké (rat), èké (market day). Low tone does not follow down step in any Igbo word.

The only place where low tone can follow down step is in grammatical construction.

$$
\begin{array}{lll}
\text { úmù + ójì } & - & \text { úmù òjì (Oji’s children) } \\
\text { úmù + ótù } & - & \text { úmù òtù (Group children) } \\
\text { úmù + Ígbò } & - & \text { úmù İgbò (Igbo's children) } \\
\text { úlò + óbì } & - & \text { úlò òbì (Obi’s house) }
\end{array}
$$

(c) Down step: This type of tone is not many in Igbo word like high tone and low tone. In the words in which it is mostly seen is in all Igbo language infinitive and in some nouns. Nevertheless, it is also observed in some 
Odinye \& Udechukwu: Igbo and Chinese Tonal Systems...

grammatical construction, like in phrase, clauses and sentences.

Down step tone has certain characteristics. They include:

i) Down step tone does not begin any single Igbo word unlike high tone and low tone.

ii) High tone and low tone do not follow down step in one Igbo word.

iii) Down step can only follow high tone in certain Igbo word like infinitive and in certain nouns.

Example:

úlò + éwú - ulọ ēwu (Goat's pen)

ísí + águ -ísí āgụ (Lion's head)

In the above examples, it was found that down step begins a word only in the grammatical construction.

(d) Down drift: This type of tone differs from other types of tone. This is because it is not seen in a single word but in sentences. It possesses the following characteristics.

i) It is not seen in a single word, in a phrase or in a clause.

ii) It is only seen in sentences. What promoted this is that it is not the pitch one takes to begin a sentence that one will equally use to end the same sentence. The same tone mark representing down drift.

Example: Onye ọbụla ga-abia akwụkwọ echi. (Everybody will come to school tomorrow)

Onye obula ga-abia akwukwo echi

\section{Kinds of Igbo tones}

\section{Inherent tone and grammatical tone}

Inherent tone is the tone a word has when pronounced alone. Example: áká (hand), ágx (lion), mbídó (beginning), ónwá (moon), 
àlà (earth). All these tones are inherent tone. If a word is used in grammatical construction like: phrases, clauses and sentences, inherent tone in a word can change. When it changes, it is called grammatical tone because it brings out the grammar in Igbo language. Every word changes its inherent tone to have grammatical tone in grammatical construction in Igbo. Example:

áká + ágụ

mbídó + ónwá

- áká ãgụ (Lion's hand)

égō + ùbé

àlà + ágụ

- mbídó ónwā (Month beginning)

- égó ubē (Money earned by selling pear)

- àlá āgụ (Lion's land)

In eụamples, agụ (Lion), ọwa (Month), ube (Pear), ala (Land), ego (Money) changed their inherent tones and then have grammatical tones. It is only adjectives that do not change its inherent tone in any grammatical construction. Some of the adjectives of Igbo include: Ọcha (white), Ọma (good), Ojii (black), Ọjọo (bad).

\section{Rules that guide tone in Igbo language}

There exist rules as regards to tone changes in Igbo language. If a word is used in any grammatical construction, the inherent tone in a word except the adjectives do change and become grammatical tone. Rules that concern these changes include:

a) Any time low tone changes in grammatical construction, it becomes down step tone. example: ụlọ + ọsa - ụlọ ọsa (Squirrel house)

b) If down step changes, it becomes high tone. example: égō + ùdù - égó ùdù (Money earned from selling clay pot)

érō + mbè - éró + mbè (Tortoise's mushroom)

c) If high tone changes in grammatical construction, it becomes down step tone. example: ónyé + ísī _ ónyé + ísī (leader)

d) Other rules of the tone, lie on how tone changes in words. In order to get those rules, words with two syllables should be used to give example. Example: A word with two syllables 
Odinye \& Udechukwu: Igbo and Chinese Tonal Systems...

might have this series of tone $\mathrm{HH}, \mathrm{LH}, \mathrm{LL}, \mathrm{HL}$. If they are grouped into two, there will be group (A) and (B).

\section{Group A}

$\mathrm{HH}$

$\mathrm{LH}$

\section{Group B}

HS

LL

HL

The rules in using group A and B in grammatical construction are:

i) If group ' $\mathrm{A}$ ' becomes $\mathrm{N}$ ' in grammatical construction, it will not change its inherent tone. example:

Ónyé + ísí (leader)

- ${ }^{\mathrm{N} 1}$ ónyé ísí ${ }^{\mathrm{N} 2}$

Ísí + òké (Rat's head)

ọịa + éwú (Goat's bush)

- ${ }^{\mathrm{N} 1}$ ísí òké ${ }^{\mathrm{N} 2}$

(In the above examples: 'N' means noun, ${ }^{\mathrm{N} 1}$ means first noun and ${ }^{\mathrm{N} 2}$ means second noun)

ii) If group ' $\mathrm{A}$ ' is following positive commanding verb, it changes its inherent tone. example,

Jèé kpùó ísí - Jèé kpùó ísí (Go and barb your hair)

iii) If group ' $\mathrm{A}$ ' becomes $\mathrm{N}^{2}$ in grammatical construction, it will change its inherent tone. Example:

Ónyé + ísí

- ${ }^{\mathrm{N} 1}$ ónyé ísí ${ }^{\mathrm{N} 2}$ (leader)

iv) If group ' $\mathrm{B}$ ' be $\mathrm{N}^{1}$ in grammatical construction, it will change its inherent tone. example: égō + òbí - égō òbí (Obi's money)

v) If group ' $\mathrm{B}$ ' be $\mathrm{N}^{2}$ in grammatical construction, it will not change its inherent tone. Example: àlà + ènwè () àlá + ènwè (monkey's land)

vi) If group ' $\mathrm{B}$ ' is following verb of positive commanding verb, it will not change its inherent tone. Example: obí + ríe + érō - obí ríe érō (Obi eat mushroom!) 


\section{The concept of Chinese tonal system}

The variety of Chinese discussed in this paper is the standard variety. This variety is called Mandarin, popularly known as 'putonghua' literally meaning "common speech". Mandarin is spoken by about 900 million people that constitute almost three quarter of Chinese speakers, and mandarin is mostly based on the pronunciation of Chinese speakers of Beijing (Katzner, 2002).

The Chinese language belongs to a separate branch of the SinoTibetan language family. It is a contour tone language. It has many dialect groups. They include Mandarin, Wu, Min, Cantonese, Hsiang, Hakka, Each of these could be said to comprise many other sub-dialects. In their spoken form most of the so-called dialects are mutually unintelligible. The Chinese language, one of the official languages in the United Nations, is spoken by more people than the people that speak any other language in the world. This is to say that Chinese has more speakers than any other languages, including English. In fact, it is said to have more than twice the number of people that speak English only that it lacks the universality which English has as it is spoken by only a few people that are not of Chinese origin (Katzner, 2002).

Tone refers to the variation of pitches. In Chinese one character has one syllable, so tone is also called character. One of the functions of the tones is to distinguish the meanings of the character. For example:

kànshū (to read a book) kànshù (to cut down a tree)

liànxí (to practice) liánxí (meet jointly)

\section{The tonal value and the tone category in Chinese}

The tonal value means the variation forms of the syllables such as a high or low, rise or fall, and long or short, that is the actual pronunciation of the tone. The tonal value is mainly formed by pitch. The five tone scale is a method marking the relative tonal value by using five points. We can draw a vertical line and divide it into four parts with five points, and mark the relative pitch on the line. Then we can take the highest pitch as five, middle-high as four, middle as 
Odinye \& Udechukwu: Igbo and Chinese Tonal Systems...

three low as two and lowest as one. The tonal category represents the types of tone in character (word) pronunciation. The following are tonal categories in Mandarin:

1. High - Level Tone

2. Middle - Raising Tone

3. Falling - Rising Tone

4. High - Falling Tone

The tonal value of Chinese can be represented in the diagrammatic sketch below.

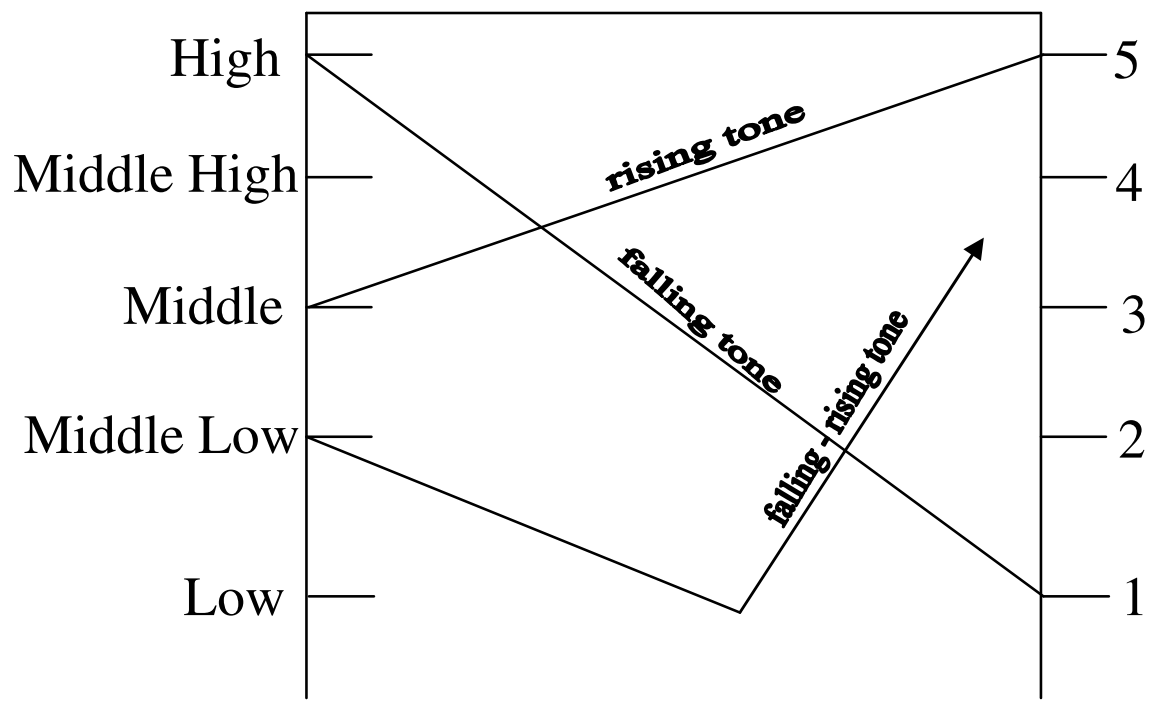

\section{Tones of Mandarin Chinese}

There are four tones in Mandarin Chinese: High - level tone, rising tone, falling-rising tone and falling tone. They are termed as the "four" tones of Modern standard Chinese".

- The Rising Tone (the second tone): Tonal value 55. The tonal value is high and level, so it is called high level tone. For example: 
dōngtiān (winter)

fēijīi (plane)

- The Rising Tone (the second tone): Tonal value 35. The tonal value rises from middle to high, so it is called the middle-rising tone. For example:

wénxué (Literature)

Értóng (children)

- The Falling - Rising Tone (the third tone): Tonal value 214. It falls from middle - low to low and then rises to middle - high, so it is called falling-rising tone. For example:

zhǔyŭ (subject)

fěnbǐ (chalk)

- The Falling Tone (the fourth tone): Tonal value 51. It falls from the highest to the lowest, so it is also termed as highfalling tone. For example:

bèikè (to prepare lesson)

bìyè (to graduate)

The table below shows the tone of Chinese

\begin{tabular}{|c|c|c|c|c|}
\hline Tonal Value & $\begin{array}{l}\text { Tone } \\
\text { Category }\end{array}$ & $\begin{array}{l}\text { Tone } \\
\text { Mark }\end{array}$ & $\begin{array}{l}\text { Characteri } \\
\text { stics of the } \\
\text { Tones }\end{array}$ & Examples \\
\hline 55(High Level) & High level & - & $\begin{array}{l}\text { Starting } \\
\text { high and } \\
\text { keeping } \\
\text { level }\end{array}$ & $\begin{array}{l}\text { Zhōng } \\
\text { (middle) }\end{array}$ \\
\hline 35 (rising) & Rising & / & $\begin{array}{l}\text { Rising } \\
\text { from } \\
\text { middle to } \\
\text { high }\end{array}$ & $\begin{array}{l}\text { Huá } \\
\text { (splendid) }\end{array}$ \\
\hline 214 (falling and & Falling and & $\checkmark$ & $\begin{array}{l}\text { Falling } \\
\text { first then }\end{array}$ & wěi \\
\hline
\end{tabular}


Odinye \& Udechukwu: Igbo and Chinese Tonal Systems...

rising)

rising

rising

(greet)

51 (high falling) Falling

Starting
high and
falling
abruptly

Dà (big)

The neutral tone and tone - sandhi

The neutral tone

Some syllables may lose their own tonal value in the flow of speech and become short and weak. This is called neutral tone. For example: the tone "žl" is falling and rising tone, but in the word "zhuōzi" (table), its tone becomes neutral. Sometimes, the neutral tone can help to distinguish the part of speech. Example:

lihai (adj) - terrible

lìhài (n) - advantages and disadvantages

dàyi (adj) - careless

dàyì (n) - main idea

The neutral tone can also help to distinguish the meaning of the words. Example:

Dōngxi (things)

Dōngxī (east and west)

Xiōngdi (younger brother)

Xiōngdì (both elder and younger brothers)

In Mandarin, neutral tones are seen in the following:

1) The structural particles such as "de, di, de", the tense particles like "zhe, le, guo" and modal particles like "ba, ma, ne, a, ma, le" etc.

2) The functional morphemes constructing nouns "zi, tou, ba,", the measure word, "ge", the word "men" which represents multiple and the pronoun "me". However, "zi" when used in one's name, is a notional word, so its tone is not neutral. Examples:

Kŏngž̆ (Confucius)

Láozĭ (lao zi) 
Mòž (mo zi)

When used as the notional morpheme in a noun, "zi" is not neutral tone either. Example:

\section{Yuánzĭ (atom) \\ Diànẓ̌ (electronic) \\ Zhōngzī (neutral)}

3) The morphemes and words used after nouns and pronouns to refer to position. Example:

Tiānshang (in the sky)

Dìxia (on the ground)

Wūli (in the house)

Zhèbian (here)

4) The directional verbs used after verbs. Example:

Chūqu (go out)

Jilai (come in)

Duŏkai (go away)

Xiàqu (go down stairs)

5) The later syllable in the reduplication form of verb or noun of monosyllabic; the second syllable in the reduplication form of disyllabic verb. Example:

Shuōshuo (to talk about)

Xiēxie (to write)

Xièxie (to thank)

Xiūxi xiūxi (to have a rest)

6) The second syllables in some disyllable single morpheme words. Example:

Bōli (glass)

Luòtuo (camel)

Gēda (lump)

7) The second syllables of some commonly used dissyllable words is generally neutral tone. Example:

Gànbu (carder)

Guānxi (relationship)

Yănjing (eyes)

Xuésheng (student) 
Odinye \& Udechukwu: Igbo and Chinese Tonal Systems...

\section{The sandhi of the falling-rising tone}

When the falling-rising tone stands along or appears at the end of the word, the sandhi will not occur. The tone sandhi of falling-rising tone occurs in the following two situations:

1. When two falling-rising tones are in succession, the first one will tend to be rising tone, and the tone value changes from 214 to 34. Example:

$\begin{array}{ll}\text { Written } & \text { Spoken } \\ \text { gǔdiăn } & \text { gúdiăn (classic) } \\ \text { yŭfă } & \text { yúfă (grammar) } \\ \text { suǒyǐ } & \text { suŏyī (therefore) }\end{array}$

When the falling-rising tone is followed by the neutral tone whose original tone is also falling-rising, there are two kinds of tonesandhi. One is the tone changes into rising tone (31), the other the middle high (21).

If three falling-rising tones are in succession, generally speaking, the first two changes into raising (34). Example:

xiăozŭzhăng

zhuănlănguăn xiáozúzăng (team leader) zhuánlánguăn (exhibition hall)

If there are four falling-rising tones; the phrase should be divided into several parts on the basis of the words, then refers to the above mentioned rules. Example:

Gı̆gŏu/cǐlǐ (absurd)

Chănpīn/zhănlă (product exhibition)

Wŭ yŏu/liăng bă/xiăo yǔsăn (I have two little umbrella)

2. Before non-falling-rising tone (high level, rising and falling tone), the falling-rising tone changes into middle-high (21). Examples:

$$
\begin{aligned}
& \text { guăngbō (radio) } \\
& \text { fŭyīn (consonant) } \\
& \text { běifāng (north) }
\end{aligned}
$$


Before rising tone:

ǒurán (by chance)

hăiyáng (ocean)

Before falling tone:

fălù (law)

fŏurèn (to deny)

\section{The Comparative Analysis of Igbo and Chinese Tonal System}

Tonal similarity in Igbo and Chinese languages

Igbo and Chinese languages have only one similarity in tonal system. They use tones to differentiate lexical items which may otherwise appear similar in forms. For instance, in Igbo we have:

$$
\begin{aligned}
& \text { ákwá (cry) } \\
& \text { ákwà (cloth) } \\
& \text { àkwá (egg) } \\
& \text { àkwà (bed) }
\end{aligned}
$$

In Chinese language, we have:

mā (mother)

má (trouble)

mă (horse)

mà (curse)

In the above examples, the meanings of the lexical items are brought out with the help of tone marks.

\section{Tonal differences in Igbo and Chinese language}

1. Igbo language belongs to the register tone languages while Chinese language belongs to contour tone languages.

2. In the types of tones, Igbo language has basically three tones: high tone, low tone and down step. The fourth tone, down drift is not a basic tone. The fifth tone is a neutral tone which is unmarked.

3. Neutral tone is only observed in Chinese language. It is a short and weak tone.

4. In Igbo language, diacritics are allowed in tone marking while in Chinese language, diacritics are not allowed. In the 
Odinye \& Udechukwu: Igbo and Chinese Tonal Systems...

above examples, the Igbo lexical items retain their diacritics while Chinese lexical items dropped their diacritics.

5. There are different methods of tone changes in both Igbo and Chinese languages. In Igbo language, when high tone changes in grammatical construction, it becomes down step tone; when low tone changes, it comes up to down step tone, and when down step tone changes, it becomes high tone. In Chinese language, when two falling-rising tones are in succession, the first one will tend to be rising tone, if the falling rising tone are in succession, generally speaking the first two tones change into rising tone; if there are four falling-rising tones, the phrase should be divided into several parts on the basis of the word.

\section{Conclusion}

This paper has been able to look into the concept of Igbo and Chinese tonal systems, importance of tone, types of tones, kinds of tones, rules that guide tones and neutral tone in Chinese language. It also studied the similarities and differences in Igbo and Chinese tones in order to pinpoint where these two languages differ as well as where they are related. This will go a long way to help students studying these two languages. Therefore, the researchers encourage learners of the two languages to develop more interest in studying them.

*Sunny Odinye PhD, Department of Igbo, African and Asian Studes, Nnamdi Azikiwe University, Awka.

*Gladys Udechukwu PhD, Department of Igbo, African and Asian Studies, Nnamdi Azikiwe University, Awka. 


\section{References}

Anagbogu, P. N., Mbah, M. B., Eme, C. A. (2001). Introduction to Linguistics. Awka: J. F. C.

Ezeuko, R. O. and Chira, A. E. (2005). Fonetiks na Fonqlqji Igbo. Awka: Kristophal Publishers.

Katzner, K. (2002). The Language of the World. London: Routledge. Roach, P. (2003). English Phonetics and Phonology. Cambridge: Cambridge University Press.

Sinolingua (1981). Say it in Chinese. China: Foreign Language Press.

Yule, G. (1996). The Study of Language. Cambridge: Cambridge University Press.

Yu, D., and Zhang, F. (2002). Chinese Culture. China: Ministry of Culture. 